\title{
COGNITIVE STRATEGIES USED IN THE VERBAL FLUENCY TEST BY ELDERLY IN SERGIPE'S COUNTRYSIDE
}

\author{
ESTRATÉGIAS COGNITIVAS UTILIZADAS NO TESTE DE FLUENNCIA VERBAL \\ POR IDOSOS DO INTERIOR DE SERGIPE
}

\author{
Kelly da SILVA ${ }^{1}$; Talita Oliveira ROCHA ${ }^{1}$; Patrícia Aparecida ZUANETTI $^{2}$; \\ Marisa Tomoe Hebihara FUKUDA ${ }^{3}$; Rodrigo DORNELAS ${ }^{4}$; \\ Raphaela Barroso GUEDES-GRANZOTTI ${ }^{5}$ \\ 1. Universidade Federal de Sergipe, Campus Prof. Antônio Garcia Filho, Lagarto, SE, Brasil. kelly.fonoufs@gmail.com; 2. Hospital \\ das Clínicas da Faculdade de Medicina de Ribeirão Preto, Ribeirão Preto, SP, Brasil; 3. Universidade de São Paulo, Ribeirão Preto, \\ SP, Brasil; 4. Universidade Federal do Rio de Janeiro, Rio de Janeiro, RJ, Brasil; 5. Universidade Federal de Sergipe, Campus São \\ Cristóvão, São Cristóvão, SE, Brasil.
}

\begin{abstract}
To analyze the cognitive strategies used in the verbal fluency test by healthy elderly without current risk of dementia. Method: Participants of the study were active elderly people, living in the countryside of the state of Sergipe, of both sexes. General identification data and health conditions were collected and the Mental State Mini Exam (MSME) and Verbal Fluency Semantics (VFS) test was applied. People with scores below the cut grade for schooling regarding the MSME were excluded from the survey. The results of these tests were analyzed qualitatively (normal or altered) and quantitatively (general score). In the VFS, the analysis was also performed according to the strategies used by the participant to recall the words (number of categories of animals cited, number of clusters performed (Clustering) and number of exchanges of cognitive strategy (Switching). The results were statistically analyzed by the Pearson correlation test. 33 elderly ( 25 females and 8 males) participated, with a mean age of 71.6 years old. The mean score in the MSME was 23.6 points and in the VFS it was 12.78 points, with a mean number of category used of 2.9, Clustering of 1.8 and Switching of 1.3. Pearson's correlation test identified important correlations between the VFS results and the number of the animals cited, Clustering and Switching categories used by the participants. Conclusion: Good general cognitive performance and language seems to be related to the cognitive strategies used in VFS, evidencing the importance of using this test in cognitive screening, even in cases of active elderly people.
\end{abstract}

KEYWORDS: Memory. Cognition. Speech. Language and Hearing Sciences. Aged.

\section{INTRODUCTION}

In recent years, several variables related to the maintenance of autonomy and independence of the elderly have been the focus of studies and actions regarding the prevention and treatment of health problems in this population (SOARES; DINIZ; CATTUZZO, 2013). Among these variables, the maintenance of cognition is highlighted, as it influences the appearance of depressive disorders and favors dependence on the performance of daily functional activities (TRINDADE et al., 2013).

Some tests may be applied in order to perform a cognitive evaluation, among them, the Mental State Mini Examination (MSME) and the verbal fluency tests (VF). These tests can be applied individually, serving as a screening tool to identify cognitive deficits or to compose more complex and comprehensive test batteries (MORRIS; HEYMAN; MOHS, 1989; ROTH et al., 1986; ZAUDIG et al., 1991).
The MSME, since its publication by Folstein, Folstein and Mchugh (1975) has become one of the most important and widespread cognitive screening instrument. It can be used clinically for the screening of cognitive alterations in the accompaniment of evolutionary diseases involving cognition and the monitoring of the results of the applied treatment (BRUCKI, et al., 2003; LOURENÇO; VERAS, 2006).

The instrument contains different cognitive parameters with questions grouped into seven categories for screening specific cognitive functions, such as temporal orientation, spatial orientation, three-word record, attention, calculation, recall of three words, language and visual constructive ability (FOLSTEIN; FOLSTEIN; MCHUGH, 1975; CHAVES, 2008).

Another test of cognitive screening used by many health professionals is the verbal fluency test, which can be used to evaluate executive and language functions (BRUCKI; ROCHA, 2004). This test provides information about semantic memory, 
the ability to retrieve information and processing of executive functions, regarding the organization of thought and strategies needed for word search (RODRIGUES; YAMASHITA; CHIAPPETTA, 2008).

The proposal is to issue the highest number of words in a stipulated time interval (GOODGLASS; KAPLAN, 1983), usually, 60 seconds. The final score is the number of words issued in the stipulated time, then, the results are compared with the normative data for age and schooling (BERTOLUCCI et al., 1994; BRUCKI et al., 2003).

However, this form of evaluation, although being the most widespread, provides little information about the underlying cognitive processes involved in verbal fluency (TROYER, 2000). Thus, to know the cognitive strategies used in the execution of this task, Clustering and Switching analyzes are performed. Clustering is the group of words issued within the same sub-category, and Switching is the subcategory exchange after the exhaustion of the sub-category used (TROYER, 2000). Thus, the Clustering strategy refers to semantic memory and Switching involves the executive function with the use of abilities such as mental flexibility and inhibition. Therefore, the qualitative analysis of this test allows the study of the cognitive strategies used to perform the lexical access (BECKER et al., 2014).

Although the VFS test is not intended to replace the MSME, it can be used to complement cognitive screening, since language is, in most cases, less affected in normal aging. For this reason, language performance has been used as a premorbidity indicator of cognitive changes (ARGIMON; STEIN, 2005). Furthermore, Amieva et al. (2008), in a longitudinal study, observed that the first cognitive decline occurred 12 years before the diagnosis of dementia and that it was detected by difficulties in semantic memory and in the formation of concepts.

Furthermore, there is strong evidence that the combined use of more than one test for cognitive screening favors the investigation of dementia, increasing the diagnostic accuracy of the pictures that involve cognitive decline (CECATO; FLORESE; MARTINELLI, 2011; APRAHAMIAN, 2011).

Thus, because the cognitive alterations in the elderly contribute to a reduction in the quality of life - since they interfere in the autonomy for the accomplishment of the daily activities -, studies about the cognition in the elderly become highly relevant. In this perspective, the objective of the present work is to analyze the cognitive strategies used in the verbal fluency test by healthy elderly without current risk of dementia.

\section{METHODS}

The research was approved by the Research Ethics Committee (CAAE: 46315915.3.0000.5546) and followed the ethical recommendations of the resolution 496/2012.

Participants were individuals aged with or above 60 years old, living in a city in the countryside of Sergipe, of both sexes. The study was conducted with elderly people attending an elderly cohabitation center. Participants who agreed to participate were clarified about the details and procedures of the study through the Free and Informed Consent Form (TCLE).

Subjects with scores below the cutoff grade for schooling in the MSME, with difficulty in answering questions orally and using antidepressants or tranquilizers were excluded.

Data collection was done from an anamnesis containing questions about the participant identification data and their health history, regarding the application of the MSME and the VFS test.

The MSME was applied as indicated by the original authors (FOLSTEIN; FOLSTEIN; MCHUGH, 1975) according to the adaptations for the Brazilian population suggested by Bertolucci et al. (1994). It considered the cutoff score of 13 points for people without literacy, 18 points for low and middle school students (up to eight years of schooling) and 26 for high schooling (more than eight years of schooling).

For the VFS test, the patient was asked to evoke the names of as many animals as possible in 60 seconds. The cutoff point used was the one suggested by Brucki et al. (1997) for people without literacy. The value for low and medium schooling it was 9 points and, for people with high schooling, it was 13 points. Scalar values were also used for statistical analysis.

The VFS test was performed according to the following strategies used by the participants: number of cited animals category (wild animals, domestic animals, farm animals, fish, birds, reptiles and insects); number of clusters (Clustering) (the sequence of at least three animals belonging to the same category) and the number of strategy switching (Switching) (number of times that the participants were exchanged between categories of animals).

The statistical analysis sought to verify the relations between the general score in the VFS and 
the number of categories of Clustering and Switching. The data were tabulated and processed in an Excel spreadsheet (Microsoft $\AA$ Office package) for descriptive data analysis and inferences. For statistical analysis, the Pearson correlation test was used. Values of $r$ (Pearson's coefficient) below 0.30 were considered as an evidence of low correlation, values between 0.41 and 0.59 were considered with moderate correlation, and values greater than 0.7 were considered as having a strong correlation.

\section{RESULTS}

The study involved 33 active elderly, with 25 female (75.8\%) and eight male (24.2\%) participants. The mean age was $71.6 \pm 5.7$ years old. On average, participants reported $2.2 \pm 2.1$ years of schooling and $11(33.3 \%)$ were not literate.
Regarding monthly income, 24 (72.7\%) people reported monthly income of up to one minimum wage and nine $(27.3 \%)$ reported income greater than one minimum wage. The professions most cited were farmer (15 people, $45.4 \%$ ) followed by hodman (5 participants, $15.1 \%$ ).

Regarding the presence of chronic noncommunicable diseases (NCDs), 16 (48.5\%) elderly patients reported systemic arterial hypertension $\quad(\mathrm{SAH}) ; \quad$ six $\quad(18.2 \%)$ hypercholesterolemia and seven (21.2\%) Diabetes Mellitus (DM).

Regarding the tests used, the mean number of participants in the VFS was $12.8 \pm 4.1$

Four people (12.1\%) had a total score in the VFS test below the cutoff point for schooling.

Table 1 shows the analysis of the VFS Test regarding the number of categories, Clustering and Switching used by the participants.

Table 1. Analysis of the strategies used by the participants to perform the verbal fluency test in the animals category

\begin{tabular}{llll}
\hline & Number of Categories & Clustering Number & Switching Number \\
\hline Mean & 2,9 & 1,8 & 1,3
\end{tabular}

Standard Deviation
$\pm 0,8$
$\pm 0,8$
$\pm 0,9$

There were positive and moderate correlations between the total score in the VFS test and the results obtained in the number of categories and exchanges. There was a strong positive correlation between the total score of this test and the number of clusters performed (table 2).

Table 2. Correlation between the results obtained in the verbal fluency test in the animals category

\begin{tabular}{llllll}
\hline & & $\begin{array}{l}\text { Number } \\
\text { categories }\end{array}$ & of Clustering Number & Switching Number \\
Total Score in the VFS & $\begin{array}{l}\text { Pearson's } \\
\text { Coefficient }\end{array}$ & R & 0,5 & 0,7 & 0,5 \\
\hline
\end{tabular}

Pearson's Correlation Test. R: Pearson's coefficient (below 0.30 were considered as evidence of low correlation, between 0.41 and 0.59 with moderate correlation, and greater than 0.7 was considered as a strong correlation).

\section{DISCUSSION}

In the last decades, the aging of the world population has been observed. In the same proportion, there has been a growing discussion regarding the importance of this phenomenon, occurring as a positive experience in which health, participation and security opportunities accompany the years lived. In this direction, the World Health Organization has used the term "active aging", seeking to obtain better quality of life for this population (OMS, 2005).

An important transversal factor of implication in active aging refers to gender (OMS, 2005). In the present study, most of the residents of the Community Center for the Elderly were women, this may be justified by the greater availability of women in seeking health care. Also, in the third age, men are more affected by health conditions that are more severe and chronic than women (COSTA E SILVA; MENANDRO, 2014), which hinders their capacity to attend dynamic spaces such as the Community Center.

Other social determinants in the construction of aging in an active way that may interfere with cognitive maintenance refer to schooling and literacy. In this study, the mean number of years studied was 2.2 years, and more than $30 \%$ of the sample was not literate. This illiteracy rate is below that estimated for the 
municipality of Lagarto regarding this age group, which is $57.1 \%$ (IBGE, 2010).

It is known that low levels of academic instruction are related to higher risks of disability at this stage of life (OMS, 2005) and may compromise the maintenance of cognition, interfering with the results of cognitive screening tests (BRUCKI et al., 2003). Regarding the results of the MSME and VFS tests, factors such as age and schooling are highlighted (DOMICIANO et al., 2014; BRUCKI et al., 1997; BERTOLUCCI et al., 1994).

In this aging process we cannot rule out the presence of Chronic Noncommunicable Diseases, such as hypertension, hypercholesterolemia and diabetes. These diseases were cited by a significant number of participants. In the reports of the participants regarding the mentioned diseases, there was similarity in the literature, since the $\mathrm{SAH}$ $(21.4 \%)$ and the DM (6.2\%) were the most prevalent, respectively, corroborating with the findings of Theme Filha, et al. (2015) in the analysis of the Brazilian profile. What differs, however, is that there was no prominence for hypercholesterolemia in the national result. In the present study, $21.2 \%$ of people reported this condition. Therefore, it is suggested that this finding could be better investigated later by other researchers.

All the people below the cutoff score for schooling in the MSME were excluded from the study, since it was intended to investigate the VFS in the elderly without relevant cognitive alterations. Therefore, all participants present adequate cognitive performance, affirming the relationship between cognitive maintenance and the fact that they are active elderly.

Meanwhile, the VFS score average was 12.8 points. However, only the final score does not provide all the important information regarding the individual's cognition. For good performance in the VFS test there is a need to use word groupings in subcategories (Clustering) and switching to a new subcategory (Switching) when the options in the Clustering strategy become exhausted. This justifies the results of these strategies being correlated with the total score, since individuals with higher scores are usually those that establish more effective cognitive strategies.
In order to perform the Clustering, the verbal memory is recruited, with the activation of the temporal lobe, since the switching strategy recruits the frontal lobe and the executive functions, since it requires mental and cognitive flexibility for its accomplishment. Another cognitive factor used in this test is the psychomotor velocity that can compromise the final number of evoked animals, even when performance in the number of Clustering and Switching is adequate (RODRIGUES; YAMASHITA; CHIAPPETTA, 2008).

The fact that four (12.1\%) elderly individuals obtained scores below the cutoff score for the VFS suggests that, regardless of whether or not the elderly are active and not institutionalized, this population needs constant cognitive assessments and comprehensive health care. Therefore, it can contribute to the detection and early intervention of cognitive alterations, interfering in a positive way in the quality of life. This important finding also indicates that only the MSME is not sufficient to assess cognitive impairment, so the VFS test contributes significantly complementing the gaps of the previous test. Although the MSME is the most used worldwide, the VFS test seems very sensitive and evaluates language more broadly.

The limitations identified in this study refer to a small number of male participants, but some studies in the Brazilian population did not identify significant differences between the sexes in the test results used in this study (BRUCKI et al., 1997).

Based on the above, other studies could be conducted with the objective of ascertaining the influence of gender on the test results, as well as the correlation with other results of general evaluation of the cognitive and health conditions of the elderly.

\section{CONCLUSION}

The total VFS score was correlated with the number of categories used, regarding the Clustering and Switching numbers performed in the VFS. Thus, good general cognitive performance and language seems to be related to the cognitive strategies used in VFS, evidencing the importance of using this test in cognitive screening, even in cases of active elderly people.

RESUMO: Analisar as estratégias cognitivas utilizadas no teste de fluência verbal por idosos saudáveis sem risco atual de demência. Participaram do estudo idosos ativos, residentes no interior do estado de Sergipe, de ambos os sexos. Foram coletados dados gerais de identificação e de condições de saúde e aplicados o teste do Mini Exame do Estado Mental (MEEM) e Fluência Verbal Semântica (FVS). Foram excluídos da pesquisa pessoas com pontuação abaixo da nota de corte para a escolaridade para o MEEM. Os resultados 
destes testes foram analisados de forma qualitativa (normal ou alterado) e quantitativa (pontuação geral). Na FVS também foi realizada a análise de acordo com as estratégias utilizadas pelo participante para evocação das palavras (número de categoria de animais citados; número de agrupamentos realizados (Clustering) e o número de trocas de estratégia cognitiva (Switching). Os resultados foram analisados estatisticamente pelo teste de correlação de Pearson. Participaram 33 idosos (25 do sexo feminino e oito do masculino), com média de idade de 71,6 anos. A pontuação média no MEEM foi de 23,6 pontos e no FVS foi 12,78 pontos, com média de número de categoria utilizada de 2,9, de Clustering de 1,8 e de Switching de 1,3. O teste de correlação de Pearson identificou importantes correlações entre os resultados da FVS e o número de categoria de animais citadas, Clustering e Switching utilizadas pelos participantes. O bom desempenho cognitivo geral e de linguagem parece estar relacionado com as estratégias cognitivas utilizadas na FVS, evidenciando a importância da utilização deste teste no rastreio cognitivo, mesmo em se tratando de idosos ativos.

PALAVRAS-CHAVE: Memória. Cognição. Fonoaudiologia. Idoso.

\section{REFERENCES}

AMIEVA, H.; LE GOFF, M.; MILLET, X. et al. Prodromal Alzheimer's Disease: successive Emergence of the Clinical Symptoms. Ann Neurol. 2008, vol. 64, pp. 492-498. https://doi.org/10.1002/ana.21509

APRAHAMIAN, I.; MARTINELLI, J. E.; CECATO, J. F.; YASSUDA, M. S. Screening for Alzheimer's disease among illiterate elderly: accuracy analysis for multiple instruments. Journal of Alzheimer's Disease. 2011, vol. 26, pp. 221-229. https://doi.org/10.3233/JAD-2011-110125

ARGIMON, I. I. L.; STEIN, M. L. Habilidades cognitivas em indivíduos muito idosos: um estudo longitudinal. Cad. Saúde Pública. 2005, vol. 21, nº 1, pp. 64-72. https://doi.org/10.1590/S0102-311X2005000100008

BECKER, N.; MULLER, J. L.; RODRIGUES, J. C.; VILLAVICENCIO, A.; SALLES J. F. Estratégias de evocação lexical com critério semântico em adultos após acidente vascular cerebral no hemisfério direito. Letrônica: Revista Digital do PPGL. 2014, vol. 7, n 1, pp. 325-347. https://doi.org/10.15448/19844301.2014.1.16838

BERTOLUCCI, P. H. F.; BRUCKI, S. M. D.; CAMPACCI, S. R.; JULIANO, Y. O Mini-exame do estado mental em uma população geral: impacto da escolaridade. Arq. Neuropsiquaitria. 1994, vol. 52, ñ 1, pp. 1-7. https://doi.org/10.1590/S0004-282X1994000100001

BRUCKI, S. M. D.; MALHEIROS, S. M. F.; OKAMOTO, I. H.; BERTOLUCCI, P. H. F. Dados Normativos para o teste de fluência verbal categoria em nosso meio. Arq. Neuropsiquaitria. 1997, vol. 55, $\mathrm{n}^{\circ}$ 1, pp. 56-61. https://doi.org/10.1590/S0004-282X1997000100009

BRUCKI, S.; NITRINI, R.; CARAMELLI, P.; BERTOLUCCI, P. H. F.; OKAMOTO I. H. Sugestões para o uso do mini-exame do estado mental no Brasil. Arq Neuropsiquiatr. 2003, vol. 61, nº 3-B, pp. 777-781. https://doi.org/10.1590/S0004-282X2003000500014

BRUCKI, S. M. D.; ROCHA, M. S. G. Category fluency test: effects of age, gender and education on total scores, clustering and switching in Brazilian Portuguese-speaking subjects. Braz J Med Biol Res. 2004, vol. 37 , $\mathrm{n}^{\circ} 12$, pp. 1771-1777. https://doi.org/10.1590/S0100-879X2004001200002

CECATO, J. F.; FLORESE, B.; MARTINELLI, J. E. Teste De Fluência Verbal e Categoria Animais e Frutas Em Idosos Analfabetos: dados de um ambulatório de geriatria. Encontro: Revista de Psicologia. 2011, vol. 14, $\mathrm{n}^{\mathrm{o}} 21$.

CHAVES, M. L. F. Testes de avaliação cognitiva: Mini Exame do estado mental, 2008. 
COSTA E SILVA, S. P.; MENANDRO, M. C. S. As representações sociais da saúde e de seus cuidados para homens e mulheres idosos. Saúde Soc. 2014, vol. 23, nº 2, pp. 626-640. https://doi.org/10.1590/S010412902014000200022

DOMICIANO, B. R.; BRAGA, D. A. K. P.; SILVA, P. N.; VASCONCELOS, T. B.; MACENA, RHM. Escolaridade, idade e perdas cognitivas de idosas residentes em instituições de longa permanência. Rev Neurocienc 2014, vol. 22, nº 3, pp. 330-6. https://doi.org/10.34024/rnc.2014.v22.8079

FOLSTEIN, M. F.; FOLSTEIN, S. E.; MCHUGH, P. R. Mini-Mental State: a practical method for grading the cognitive state of patients for clinician. J Psychiatr Res 1975, vol. 12, pp. 189-198.

https://doi.org/10.1016/0022-3956(75)90026-6

GOODGLASS, H., KAPLAN, E. The Assessment of Aphasia and Related Disorders. $2^{\mathrm{a}}$ ed. Philadelphia: Lea \& Febiger; 1983.

IBGE - Instituto Brasileiro de Geografia e Estatística. Pesquisa Nacional por Amostra de Domicílios. Rio de Janeiro: IBGE; 2010 [acesso em 4 ago 2016]. Disponível em:

http://cidades.ibge.gov.br/xtras/temas.php?codmun=280150\&idtema $=79$.

LOURENÇO, R. A.; VERAS, R. P. Mini-Exame do Estado Mental: características psicométricas em idosos ambulatoriais. Rev. Saúde Publica. 2006, vol. 40, nº 4, pp.712-9. https://doi.org/10.1590/S003489102006000500023

MORRIS, J. C.; HEYMAN, A.; MOHS, R. C. et al. The consortium to establish a registry for Alzheimer's disease (CERAD): Part 1. Clinical and neuropsychological assessment of Alzeheimer's disease. Neurology. 1989, vol. 39, pp. 1159-1165. https://doi.org/10.1212/WNL.39.9.1159

ORGANIZAÇÃO MUNDIAL DE SAÚDE. Envelhecimento ativo: uma política de saúde / tradução Suzana Gontijo. - Brasília: Organização Pan-Americana da Saúde, 2005.

RODRIGUES, A. B.; YAMASHITA, E. T.; CHIAPPETTA, A. L. M. Teste de fluência verbal no adulto e no idoso: Verificação da aprendizagem verbal. Rev CEFAC. 2008, vol. 10, nº 4, pp. 443-445.

https://doi.org/10.1590/S1516-18462008000400004

ROTH, M, T. Y. M. B. K; MOUNTJOY, C. Q. et al. CAMDEX: a standardized instrument for the diagnosis of mental disorder in the elderly with special reference to the early detection of dementia. Br J Psychiatry. 1986, vol. 149, pp. 698-709. https://doi.org/10.1192/bjp.149.6.698

SOARES, R. M.; DINIZ, A. B.; CATTUZZO, M. T. Associação entre atividade física, aptidão física e desempenho cognitivo em idosos. Motri. 2013, vol. 9, n 2, pp. 84-93.

https://doi.org/10.6063/motricidade.9(2).2670

THEME FILHA, M. M.; SOUZA JUNIOR, P. R. B; DAMACENA, G. N.; SZWARCWALD, C. L. Prevalência de doenças crônicas não transmissíveis e associação com autoavaliação de saúde: Pesquisa Nacional de Saúde, 2013. Rev bras epidemiol. 2015, vol. 18, nº 2, pp. 83-96. https://doi.org/10.1590/19805497201500060008

TRINDADE, A. P. N.; BARBOZA, M. A.; OLIVEIRA, F. B.; BORGES, A. P. O. Repercussão do declínio cognitivo na capacidade funcional em idosos institucionalizados e não institucionalizados. Fisioter Mov. 2013, vol. 26, n ${ }^{\circ}$ 2, pp. 281-289. https://doi.org/10.1590/S0103-51502013000200005

TROYER, A. K. Normative Data for Clustering and Switching on Verbal Fluency Tasks. J Clin Exp Neuropsychol. 2000, vol. 22, n³, pp.370-378. https://doi.org/10.1076/1380-3395(200006)22:3;1-V;FT370 
Cognitive strategies...

SILVA, K. et al.

ZAUDIG, M.; MITTELHAMMER, J.; HILLER, W. et al. SIDAM: a structured interview for the diagnosis of dementia of the Alzheimer's type, multiinfarct dementia and dementias of the other etiology according to ICD10 and DSM-III-R. Psychol Med. 1991, vol. 21, pp. 225-236. https://doi.org/10.1017/S0033291700014811 